\title{
Effects of Non-Thermal Plasma on Yeast Saccharomyces cerevisiae
}

\author{
Peter Polčic ${ }^{1, * \mathbb{D}}$ and Zdenko Machala ${ }^{2}$ (D) \\ 1 Department of Biochemistry, Faculty of Natural Sciences, Comenius University in Bratislava, \\ Mlynská dolina CH1, Ilkovičova 6, 84215 Bratislava, Slovakia \\ 2 Division of Environmental Physics, Faculty of Mathematics, Physics, and Informatics, \\ Comenius University in Bratislava, Mlynská dolina F2, 84248 Bratislava, Slovakia; machala@fmph.uniba.sk \\ * Correspondence: peter.polcic@uniba.sk; Tel.: +421-2-60296-398
}

\section{check for}

updates

Citation: Polčic, P.; Machala, Z. Effects of Non-Thermal Plasma on Yeast Saccharomyces cerevisiae. Int. J. Mol. Sci. 2021, 22, 2247. https:// doi.org/10.3390/ijms22052247

Academic Editor: Eva Horvathova

Received: 30 January 2021

Accepted: 20 February 2021

Published: 24 February 2021

Publisher's Note: MDPI stays neutral with regard to jurisdictional claims in published maps and institutional affiliations.

Copyright: (c) 2021 by the authors. Licensee MDPI, Basel, Switzerland. This article is an open access article distributed under the terms and conditions of the Creative Commons Attribution (CC BY) license (https:// creativecommons.org/licenses/by/ $4.0 /)$.

\begin{abstract}
Cold plasmas generated by various electrical discharges can affect cell physiology or induce cell damage that may often result in the loss of viability. Many cold plasma-based technologies have emerged in recent years that are aimed at manipulating the cells within various environments or tissues. These include inactivation of microorganisms for the purpose of sterilization, food processing, induction of seeds germination, but also the treatment of cells in the therapy. Mechanisms that underlie the plasma-cell interactions are, however, still poorly understood. Dissection of cellular pathways or structures affected by plasma using simple eukaryotic models is therefore desirable. Yeast Saccharomyces cerevisiae is a traditional model organism with unprecedented impact on our knowledge of processes in eukaryotic cells. As such, it had been also employed in studies of plasmacell interactions. This review focuses on the effects of cold plasma on yeast cells.
\end{abstract}

Keywords: cold plasma; yeast; oxidative stress

\section{Introduction}

Non-thermal (cold) plasmas, also referred to as non-equilibrium plasmas, can be generated by various types of electrical discharges, such as coronas, sparks, dielectric barrier or radio-frequency discharges, at low, as well as at atmospheric pressure. They are ionized gases, in which the electrons acquire high energy, but the gas particles retain a relatively low, often even ambient, temperature. Exposure to non-thermal (cold) plasmas is known to affect living cells in a way that depends on plasma characteristics and dose, as well as on the cell type. Since the treatment of cells by cold plasma may produce desirable effects, a number of practical applications have arisen from investigation of plasma-cells interactions. These include inactivation of microorganisms for the purpose of disinfection or sterilization [1-5], food treatment to prevent spoilage [6] or induction of germination in seeds and enhanced plant growth [7]. Treatment by plasma has been proven to support wound healing [8] and the plasma devices for such treatment have already been approved in several countries [9]. The techniques are being developed, by which specific cells, e.g., cancer cells, can be selectively killed. These applications could, thus, potentially be useful for the treatment of various pathologies, such as cancer $[1-4,10,11]$. The mechanisms involved in cell killing by cold plasmas are, however, still poorly understood and dissection of cellular pathways as well as identification of cell components affected by plasma using simple eukaryotic models is needed.

Yeast Saccharomyces cerevisiae has been a traditional eukaryotic model organism with an unprecedented impact on biochemistry and cell biology [12]. It has been used to characterize countless fundamental processes in eukaryotic cells, including gene expression, the cell cycle progression and membrane trafficking, to name a few. Although yeast may not have some of the pathways present in specialized types of animal cells, they often contain individual components of these pathways conserved and may, thus, be used to study specific subroutines of these pathways, as is in a case of many human diseases, 
human cell death pathway (apoptosis) [13], or even in the biology of neurons [14] or viruses [15]. Moreover, mammalian (e.g., human) components that are completely absent in yeast can often be expressed in yeast in order to study them in a simple 'humanized' yeast model system [16,17]. With a powerful battery of genetic and biochemical methods that cannot be rivalled by any other eukaryotic system, yeast are being also recognized as a perspective model for studying the effects of plasma on cells. This review focuses on our current knowledge of interactions of cold plasma with the cells of this model organism.

\section{Plasma Treatment of Yeast Cells}

Cold plasma has been well characterized as extremely toxic for bacteria, which led to the development of different cold-plasma based technologies for decontamination of various materials [5]. Sensitivity of eukaryotic cells, including yeast, to plasma treatment is generally lower as compared with bacteria, but significant fraction of eukaryotic cells can be killed by cold plasma in a dose-dependent manner (with plasma "dose" usually expressed as the plasma treatment time) [18-20]. The effectivity of killing and likely also molecular mechanisms involved in cell killing also depend on the mode of the action of plasma on cells. While many different settings are used to experimentally treat cells by cold plasma, two basic modes of treatment differ significantly. These are the direct treatment of cells, in which cells are exposed to the plasma discharge, or indirect, in which cells are incubated in a liquid medium that was treated by plasma, e.g., plasma-activated water. Somewhere in between these two extremes are the settings (plasma jets), in which a carrier gas moves through the discharge and carries the generated plasma to the treated material (e.g., cells). Examples of typical experimental setups used for treating of cells with cold plasma are shown in Figure 1.

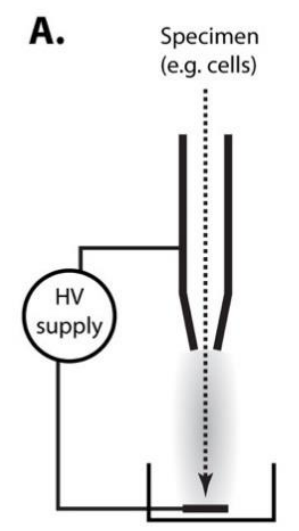

B.

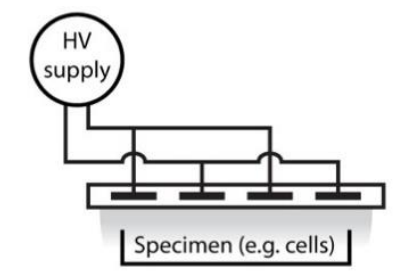

Specimen (e.g. cells)
C.

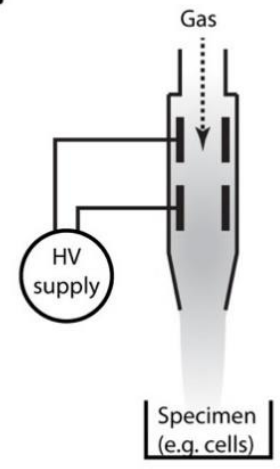

Figure 1. Typical experimental settings used for plasma treatment of cells. (A) Treated specimen is pumped through the hollow electrode and passes through electrical discharge, in which plasma (in all panels depicted in grey) is generated. (B) Plasma is generated by a discharge between electrodes separated by insulating dielectric barrier. Specimen is exposed to the plasma. (C) In plasma jet devices, plasma is generated between two electrodes inside a nozzle and streaming gas transmits plasma to the specimen. In all these settings, specimen may either contain treated cells (direct treatment) or certain type of medium (e.g., water), in which cells are subsequently incubated (indirect treatment).

Chemical composition of plasma is rather complex and may differ in different experimental settings, depending on gases in the plasma and surrounding environment. In plasma generated in atmospheric air, a broad array of reactive oxygen species (ROS) and reactive nitrogen species (RNS) can be detected. These include radicals such as hydroxide $\left({ }^{\bullet} \mathrm{OH}\right)$, oxygen $\left({ }^{\bullet} \mathrm{O}\right)$, nitrogen $\left({ }^{\bullet} \mathrm{N}\right)$, nitric oxide $\left({ }^{\bullet} \mathrm{NO}\right)$, hydroxyperoxyl $\left(\mathrm{HO}_{2}\right)$; ions, e.g., superoxide $\left(\mathrm{O}_{2}{ }^{\bullet-}\right)$; and other oxidants, e.g., ozone $\left(\mathrm{O}_{3}\right)$ or singlet oxygen $\left({ }^{1} \mathrm{O}_{2}\right)[21,22]$. Both in air and in the water treated by plasma, these particles react with each others and with water, so that other particles, such as hydrogen peroxide $\left(\mathrm{H}_{2} \mathrm{O}_{2}\right)$, nitrite $\left(\mathrm{NO}_{2}{ }^{-}\right)$ and nitrate $\left(\mathrm{NO}_{3}{ }^{-}\right)$are generated and the treated water typically gets acidified $(\mathrm{pH} \sim 3.2$, 
unless buffered) [23]. Short-lived but reactive peroxynitrite $\left(\mathrm{ONOO}^{-}\right)$has also been detected $[23,24]$.

As one would expect, significantly more yeast cells are killed by direct plasma treatment than when cells are incubated in plasma-activated water [25]. These results indicate that in direct treatment regime, a significant portion of cells dies immediately due to the exposure to the factors present in the electric discharge (e.g., electric field, short-living reactive particles, UV irradiation). Additionally, a portion of cells that survive the discharge dies due to the presence of reactive particles generated in the discharge and surviving in the plasma-activated water for significant periods of time after the discharge. From a comparison of survival rates of directly and indirectly treated cells, it appears that these two components of cell killing effects act together, likely in synergy.

When survival of yeast cells after treatment with $\mathrm{He} / \mathrm{O}_{2}$ plasma jet was assessed in different surrounding media, the same parameters of plasma were found to induce different changes [26]. The lowest survival rates were observed when cells were treated in water, with the effect being less severe in phosphate buffered saline (PBS) and mildest in YPD (yeast extract, peptone, dextrose), where survival rates were significantly higher. Cellprotective effect of PBS is probably caused by its buffering capacity and salt strength rather than osmotic stabilization, as lowering the salt concentration leads to a lowered protective effect that cannot be reproduced by using sorbitol. Acidification of media appears to play a role, but it must be the combination of $\mathrm{pH}$ and the presence of reactive particles that affects the survival, since yeast normally tolerate the corresponding acidic $\mathrm{pH}$ [27]. The weak effect of plasma on cells in YPD can, in addition to its buffering capacity, likely be explained by sequestering reactive particles by the components of the medium. For example, if one only considers the reactions of reactive particles from the plasma with proteins, there is roughly $100 \times$ more mass of peptides in YPD ( $2 \%$ peptone) than is proteins in treated cells (at $10^{7}$ cells $/ \mathrm{mL}$ ).

\section{Plasma-Induced Cell Death in Yeast}

Analyses of plasma-treated yeast cells revealed numerous changes. Visualization of treated cells by electron scanning microscopy uncovered changes in cell morphology and in the cell wall. When yeast cells on a filter were treated with $\mathrm{He} / \mathrm{O}_{2}$ plasma jet, changes resembling peeling have been observed in the cell wall [18]. Different changes were observed when yeast were treated in a suspension. Under these conditions, a portion of treated cells acquired shrunken and crashed appearance, with both the severity and the incidence of changes depending on the surrounding medium [26]. The most severe and frequent changes were observed when cells were treated in water, less severe in saline solution and mildest in YPD, which correlates with the survival rate. Changes in appearance of cells were also observed by transmission electron microscopy.

Since it has been well-established that properly dosed plasma treatment can induce programmed cell death by apoptosis in mammalian cells [4,10,28-30], plasma-treated yeast cells were also investigated for the presence of markers of programmed cell death. Although yeast do not have the pathway that directly corresponds to the mammalian apoptotic pathway, it has been generally accepted that yeast cells can undergo regulated cell death and some of the components of yeast cell death pathways are homologous to their mammalian counterparts with well-established roles in apoptosis [31-35]. Interestingly, several changes that are considered as typical hallmarks of regulated cell death have been observed in yeast cells treated with $\mathrm{He} / \mathrm{O}_{2}$ plasma jet [36] or directly by a corona discharge [37]. These changes involve generation of a population of cells that are stained with Annexin-V, due to the exposure of phosphatidylserine at the cell surface, while they are not stained with propidium iodide, indicating the intact plasma membrane [36,37]; chromatin condensation that can be visualized by staining with DAPI $\left(4^{\prime}, 6\right.$-diamidino-2phenylindole); decrease in mitochondrial transmembrane potential revealed by staining with TMRM (tetramethylrhodamine methyl ester) and cell cycle arrest in G1 phase [36]. These observations may indicate that, at least partially, the dying observed in yeast after the 
plasma treatment may be attributed to regulated cell death that is triggered as a reaction to, either cell damage or to the presence of reactive particles originating from plasma itself. However, when the participation of known components of yeast cell death pathway on the plasma-induced dying was analyzed, it was found that mutant yeast strains that lack these components retain unchanged death rate as compared with the wild type strains [25]. The tested yeast cell death components involved the yeast metacaspase Yca1p [38], yeast homologue of mammalian apoptosis-inducing factor Aif1p [39], and endonuclease G Nuc1p [40]. Contrary to the detection of apoptotic markers, these results indicate that participation of Yca1p, Aif1p and Nuc1p is not required for plasma-induced cell death as it would be expected in the case of plasma-induced apoptosis. Dying of cells is thus likely directly caused by malfunction of vital cellular components due to the damage caused by plasma rather than a cell response to the damage by the activation of cell death program. The presence of apoptotic markers in dying cells may result from activation of some of the downstream subroutines of regulated cell death pathway that may in this case accompany the unregulated death. However, it was not ruled out that regulated cell death pathways that do not rely on function of Yca1p, Aif1p and Nuc1p may exist in yeast and be activated in the cells damaged by plasma. Bacause in apoptosis, or in other forms of programmed cell death, cells are dying due to the execution of intrinsic cell killing program rather than directly due to the damage, to prove that apoptosis participates in cell killing by plasma, it has to be shown that blocking of participating cell death pathway would result in an increased cell survival after treatment with plasma.

\section{Effect of Plasma on Membranes and Energy Metabolism}

Membrane lipids are well known target of oxidative damage in cells. Oxidants, such as free radicals, react with lipids containing one or more carbon-carbon double bond, especially polyunsaturated fatty acids (PUFAs), resulting in lipid peroxidation. This process not only leads to the damage of cell membranes but also generates further toxic reactive species (see [41] for review). One of the major products of lipid peroxidation is malonedialdehyde (MDA), which is also often used as a marker of lipid peroxidation as it can be easily quantified by a reaction with thiobarbituric acid [42]. Production of MDA has been previously described in plasma-treated bacteria Escherichia coli [19,43,44].

Yeast $S$. cereviseae (similar to E. coli) do not produce polyunsaturated fatty acids with more than one double bond $[45,46]$, but the generation of MDA was described in the plasma-treated yeast cells $[36,47]$, indicating that yeast lipids get peroxidated under these conditions. In the same study, it was also shown that the same treatment leads to the leakage of proteins as well as potassium ions $\left(\mathrm{K}^{+}\right)$from the treated cells to the surrounding medium, to the loss of the membrane potential at cytoplasmic membrane and to an increase in the intracellular $\mathrm{pH}$. These findings together clearly indicate that the plasma treatment disrupts the integrity of yeast cytoplasmic membrane.

Although it has not been specifically shown that intracellular membranes of yeast are damaged by plasma, it is highly probable. An increase in intracellular $\mathrm{Ca}^{2+}$ observed in plasma-treated cells [47] can likely be attributed to the disruption of the barrier function of cellular membranes. Staining of yeast cells with TMRM or JC-1 further indicated that, in plasma-treated yeast cells, mitochondria may not be able to maintain transmembrane potential $(\Delta \psi)[36,47]$, resulting in a dramatic decrease in cellular ATP level [47]. This may be, indeed, caused by the damage to the inner mitochondrial membrane due to lipid peroxidation. On the other hand, numerous causes other than membrane damage could explain the loss of membrane potential, including the changes in metabolism of the cell due to oxidative damage of many cellular enzymes or, as it has also been suggested [47], by opening of the mitochondrial permeability transition pore (PTP). As the latter is a highconductance nonspecific channel in mitochondrial membranes that opens in response to $\mathrm{Ca}^{2+}[48]$, its opening and participation on the dissipation of mitochondrial $\Delta \psi$ is consistent with the increase in intracellular $\mathrm{Ca}^{2+}$. Here, however, it should be mentioned that PTP in yeast mitochondria differs from that known in mammalian cells in several aspects. 
One of these is that due to the absence of $\mathrm{Ca}^{2+}$ uptake transporter in yeast mitochondria, yeast PTP can only be opened in vitro (in isolated mitochondria) in the presence of a $\mathrm{Ca}^{2+}$ ionophore [49]. Although the role of PTP in cell death in yeast has been suggested, mostly based on the analogy with mammalian cells [50], there is no evidence so far of PTP opening in yeast in vivo nor its participation in any physiological process in yeast has been proven.

It may be interesting to note here that most of the data on ion homeostasis, $\mathrm{pH}$ and transmembrane potential are based on the measurements that rely on fluorescent probes and their accumulation in relevant cell compartments. Some of these data, thus, may be significantly biased by the disruption of the integrity of membranes that clearly happens upon the plasma treatment.

\section{Plasma Damage to DNA}

Cellular DNA represents another well-established target of plasma. Chemical changes induced by plasma treatment of isolated DNA have been intensively studied and involve the formation of DNA strand breaks, dimerization and modification of bases [51]. In eukaryotic cells, the formation of single-strand and double-strand breaks [51,52], as well as creation of oxidized bases such as 8-oxodeoxyguanosine [51,53], has been described. These changes are subject to DNA repair mechanisms but may result in mutations, or in cell death if the damage exceeds the capacity of the DNA repair system. Based on the ability of plasma to induce mutations, a technique called atmospheric and room temperature plasmas (ARTP) mutagenesis has been developed [54]. The ARTP mutagenesis, which can generate higher mutation rate than traditional random mutagenesis techniques, such as UV irradiation or chemical mutagenesis, was successfully used to generate mutants of several microorganisms, including bacteria, yeasts and algae, mostly for the purpose of generating strains with desired biotechnological properties [55,56].

To study the possible effect of plasma on the chromosomal stability in yeast, a sensitivity of wild-type and rad51 mutant to the plasma treatment was measured. RAD51 encodes for a strand exchange protein that is required for effective homologous recombination in the process of DNA damage repair. Yeast strains lacking a functional Rad51p are therefore hypersensitive to agents that induce the formation of double-strand breaks in DNA [57]. When treated with non-thermal atmospheric plasma, Rad51-defficient mutant was found to be significantly more sensitive as compared with wild type, indicating that the reparation of double-strand breaks contributes to the survival after plasma treatment [58]. To confirm that the increased sensitivity of this mutant to plasma really is a result of defective homologous recombination, two other deletion mutants lacking proteins participating in the same pathway have been tested for sensitivity to plasma treatment [58]. Both mutants, lacking either Rad52p, a protein of the same epistatic group as Rad51p, that facilitates the Rad51p binding to DNA $[59,60]$, or Mec1p, a protein kinase required for DNA damage checkpoint (yeast analog of human ATR) [61,62], were also found to be more sensitive to the air plasma treatment. Moreover, when yeast cells expressing Rad52-GFP were treated with plasma, green fluorescent foci were observed in cell nuclei, resembling those induced by phleomycin, an antibiotic known to induce double-strand breaks in DNA. These foci represent the Rad52-GFP sequestered on the damaged DNA. Their formation thus indicates that the plasma-induced damage in DNA is actually recognized by Rad52p. Interestingly, the induction of double-strand breaks that happens in atmospheric air plasma was not observed when plasma was generated in $\mathrm{N}_{2}$, indicating that the particles that react with DNA to cause this type of damage may not be present in plasma under these conditions [58].

Another type of DNA damage that was detected in plasma-treated yeast cells is the formation of DNA-protein crosslinks [63]. This is a specific type of DNA damage, in which proteins are covalently bound to DNA. As the resulting lesions can be bulky, this type of DNA damage usually interferes with transcription and replication [64]. In the case of plasma treatment, the nuclear proteins, e.g., histones, are likely attacked by ROS and RNS originating in plasma to form reactive intermediates that then react with DNA [63]. 
The ability of plasma to induce the formation of DNA-protein crosslinks in cells may be particularly interesting from the perspective of the use of plasma in cancer therapy because induction of DNA-protein crosslinks is particularly toxic for dividing cells and represents a mechanism, by which several anti-cancer chemotherapeuticals work. Although these drugs mostly act by binding the specific enzymes to DNA, some of them, such as cis-platin, have been shown to crosslink histones to DNA $[65,66]$.

\section{Genetic Dissection of Plasma-Induced Changes in Yeast}

Yeast S. cerevisiae is the first eukaryotic organism, the genome of which was completely sequenced [67]. Mutants with deletion of any non-essential gene are either available from systematic genomic studies, such as Euroscarf collection [68], or can be easily prepared in any genetic background thanks to the high efficiency of homologous recombination in yeast $[69,70]$. Testing of the sensitivity of such mutants thus appears a reasonable strategy, by which enzymes or cellular components that affect the survival after plasma treatment may be identified. Using this approach, several genes have been found to affect the survival of cells after treatment with plasma.

Since the major cell killing effect of the plasma is generally attributed to ROS and RNS, deletion strains lacking enzymes that inactivate such reactive particles have been tested in the plasma treatment. There are two superoxide dismutases in S. cerevisiae. The cytosolic $\mathrm{Cu} / \mathrm{Zn}$-superoxide dismutase Sod1p and the mitochondrial Mn-containing Sod2p are components of an inducible system of cellular protection against superoxide, but expression and activities of both are also detectable in exponentially growing cells [71-73]. Similarly, the protection from hydrogen peroxide is provided by two catalases, cytosolic Ctt1p [74] and peroxisomal Cta1p [75,76]. While yeast strains lacking either one of the two superoxide dismutases (SODs) were found to be more sensitive both towards the direct plasma treatment and towards the incubation in the plasma-activated water, mutants lacking any of the two catalases did not differ from the wild type control [25]. Higher sensitivity of SOD-deletion mutants suggests that superoxide must play a significant role in killing cells by plasma, and that the superoxide dismutases expressed in cells are able to considerably reduce the concentration of superoxide. These results are perfectly consistent with increased plasma resistance observed in strains overexpressing SOD1 or SOD2 [36]. On the other hand, the negligible effect of the deletion of the genes encoding for catalases on survival after the plasma treatment supports the idea that hydrogen peroxide does not play a key role in plasma-induced killing of yeast [25]. However, here, one has to be cautious in interpreting this result in such a way, as the deletion of CTT1 and CTA1 generally does not affect the survival of yeast when treated with comparable concentrations of hydrogen peroxide [77].

In another study that employed a similar approach, plasma jet treatment was applied to a set of mutants with individual deletions of genes participating in oxidative stress response and cell cycle regulating pathways. Several of the tested mutants were found to be more sensitive to plasma than wild type [78]. From the oxidative stress pathway, these were deletions of genes HOG1, SSK2, SKN7 and ASK10. Products of these genes participate at stress responsive Mitogen-activated protein kinase (MAPK) cascade, an evolutionarily conserved pathway that signals the stress to the cell nucleus and governs the transcriptional regulation of many genes involved in stress response [79]. In this cascade, Hog1p represents a key protein kinase (MAPK) that upon its activation enters the cell nucleus and phosphorylates a repressor protein Sko1p to inactivate it. This in turn activates the expression (transcription) of target genes [80,81]. Hog1p is activated by upstream kinases Pbs2p (MAPK kinase, MAPKK) and either of two MAPKK kinases (MAPKKK) Ssk2p or Ssk22p. Signalization of stress to the MAPK cascade is mediated by a pathway referred to as multistep phosphorelay, which is a yeast homologue of prokaryotic two-component pathway [82]. It consists of a membrane sensor kinase Sln1p, phosphate transfer protein Ypd1p and Ssk1p that directly regulates Ssk2p. Increased sensitivity of mutants lacking Hog1p or Ssk2p indicates that signaling by MAPK cascade is involved in the response of cells to plasma. The participation of this MAPK cascade was further corroborated by 
detection of phosphorylation of Hog1p in plasma-treated wild type cells [26]. Interestingly, while three major MAP kinases exist in yeast, Fus3p, Hog1p, and Slt2p, no phosphorylation of Fus $3 p$ and Slt2p was induced under same conditions.

Skn7p is another target of multistep phosphorelay [83]. It is a stress-responsive transcription factor $[79,84,85]$ that regulates the oxidative stress-induced expression of anti-oxidant genes, including cytosolic catalase (CTT1), cytosolic superoxide dismutase (SOD1) and others [86]. Under the conditions of stress, Skn7p is also known to be regulated by Ask10p $[87,88]$. Decreased resistance of $s k n 7$ and ask10 mutants to plasma indicates that, among other stress response pathways, this pathway plays a consequential role in cell survival after the plasma treatment [78].

All four mutants defective in genes required for the regulation of cell cycle that were investigated, CDC28, CLN3, SWI4 and SWI6, were found to be hypersensitive to plasma treatment [78]. Cdc28p is a catalytic subunit of cyclin-dependent kinase that throughout the progression of cell cycle associates with cyclins, such as $C \ln 3 p$, that regulate its activity and selectivity [89]. The expression of genes required for $\mathrm{S}$ phase relies on transcriptional activators known as SBF (SCB-binding factor) and MBF (MCB-binding factor). These factors are heterodimers of Swi4p/Swi6p and Mbp1p/Swi6p, respectively, and their activity is regulated by binding of Whi5p repressor [90,91]. To proceed from G1 to $S$ phase, $C \ln 3 p / C d c 28 p$ complex must phosphorylate the Whi5p, which then releases active SBF and MBF to activate the transcription of genes containing SCB and MCB elements in their promoters [92].

Increased sensitivity of mutants with deleted CLN3, SWI4, SWI6 or diminished expression of $C D C 28$ (which is an essential gene) suggests that flawless regulation of cell cycle may be important for the ability of cells to deal with stresses induced by plasma. It may likely be attributed to the DNA damage checkpoint failure in mutant yeast strains upon the plasma-induced damage of DNA. In the case of swit and swi6 mutants, this seems to be in agreement with the fact that Swi6p is a target of regulation by Mec1p (see above). In response to DNA damage, Mec1p phosphorylates the protein kinase Rad53p, which in turn phosphorylates Swi6p $[93,94]$. A lack of Swi6p phosphorylation due to mutation in its phosphorylation site is known to shorten a delay at the checkpoint in case of DNA damage [94]. The lack of the proper response to DNA damage induced by plasma may thus explain decreased survival of swi6 and swi4 mutants. Another possible explanation for increased sensitivity of swi6 mutant may not involve the DNA damage, but rather reflect the fact that Swi6p also acts as an oxidative stress sensor by directly sensing redox status through a specific cysteine residue [95].

As the diminished expression of $C D C 28$ is known not to increase the sensitivity of cells to DNA damaging agents [96], failure of the checkpoint does not explain the increased plasma sensitivity of $c d c 28$ and $c \ln 3$ mutants. It is, thus, possible that, in addition to the proper function of G1/S checkpoint, which provides the cell with the chance to repair the damage before proceeding to $S$ phase, proper regulation of some additional, yet to be identified, events in a cell cycle is crucial for the recovery from the plasma-induced stress.

\section{Plasma Treatment Induces Multiple Stress-Response Pathways}

When the response of yeast cells to cold plasma was investigated using the GFPlabelled reporter fusion proteins, activation of multiple stress response pathways has been detected. Yap1p is a leucine zipper transcription factor that is known to translocate from the cytoplasm to the nucleus under conditions of oxidative stress, e.g., after $\mathrm{H}_{2} \mathrm{O}_{2}$ treatment, to activate the transcription of anti-oxidant stress response genes [97]. It directly reacts to the oxidative status within the cell as its localization is governed by creation of disulfide bonds within specific region of the protein that also contains a nuclear localization signal $[98,99]$. When localization of Yap1-GFP was investigated in plasma-treated cells, a significant portion of green fluorescence was found to relocate from the cytoplasm to the cell nucleus within minutes after the plasma treatment [100]. This observation indicates that plasma treatment induces the oxidative stress in yeast cells that is sensed by Yap1p. 
Msn2p and Msn4p are the general stress response factors that are stochastically distributed between the cell cytoplasm and nucleus in normal (non-stress) conditions, but increase their relative distribution to the nucleus in response to various stress conditions, including heat shock, osmotic shock, oxidative stress and low $\mathrm{pH}[101,102]$. In the nucleus, these factors activate the transcription of genes containing the stress response element STRE $[101,103]$. In plasma-treated cells, fusion proteins containing either of these two proteins and green fluorescent protein, Msn2-GFP and Msn4-GFP, translocate from the cytoplasm to the nucleus [100]. As it can be expected, the expression of two genes encoding for heat shock proteins HSP30 and SSA4, that are involved in this stress response pathway and are the target genes of Msn2p and Msn4p (and contain STRE) [104,105], is induced in plasma-treated cells [100]. This clearly indicates that the signalization by this pathway in fact does affect the expression of genes under conditions of plasma treatment.

Chaperones that are involved either in protein folding or in protein maintenance under various stress conditions and have been shown to respond to plasma treatment involve Hsp104p [100], Tsa1p and Ssa1p [106]. Hsp104p is a heat shock protein known to facilitate the disassembly of protein aggregates that are formed under stress conditions [107]. Aggregates of Hsp104-GFP, similar to those formed in cells after a heat shock, can be observed in the cytoplasm of yeast cells treated with plasma [100]. Moreover, the production of centrifugable insoluble protein aggregates, as well as protein ubiquitination, both in a fashion similar to that observed after heat-shock, were detected in the same study. Tsa1p is a cytosolic thioredoxin peroxidase that participates at the protection of cells against oxidative stress $[108,109]$. Ssa1p is a heat shock protein, a cytosolic member of HSP70 family, that assists in protein folding, prevents protein aggregation or disassembles protein aggregates $[110,111]$. Tsa1-GFP and Ssa1-GFP fusions were shown to form aggregates in the cytosol in response to plasma treatment [106]. Unlike with Hsp104p, similar change is not induced by heat shock but can be induced by treatment of cells with $\mathrm{H}_{2} \mathrm{O}_{2}$.

Accumulation of unfolded or unproperly folded proteins in endoplasmic reticulum (ER) is referred to as stress of endoplasmic reticulum (ER stress). It can be experimentally induced, e.g., by heat shock or by treatment of cells with reducing agents, such as dithiotreitol (DTT) or $\beta$-mercaptoethanol. From the pathways known to respond to ER stress, pathway that relies on Ire1 is the only one described in yeast $[112,113]$. Ire1p is a transmembrane protein in the membrane of ER that acts as a sensor of accumulation of unfolded proteins in the lumen of ER [114]. Signalization by Ire1p is triggered by the dimerization that leads to the autophosphorylation and activation of its ribonuclease cytosolic domain. Processing of a specific pre-mRNA (HAC1U) by active Ire1p ribonuclease then enables the synthesis of Hac1p transcription factor that affects the expression of relevant genes [115]. The dimerization of IreIp is believed to result from the lack of the binding of chaperone BiP to the ER luminal domain of Ire1p, which occurs when all of the BiP is engaged in binding to unfolded proteins in ER lumen [116]. The rearrangement of fluorescent fusion Ire1-GFP was observed following the treatment with non-thermal plasma. Such rearrangement is consistent with Ire1p activation, as a similar effect was also observed in control cells treated with DTT [100]. Moreover, in the cells treated with plasma, an increase in fraction of BiP that formed sedimentable complexes with unfolded proteins was observed [106]. To test whether plasma treatment indeed affects the traffic of proteins through the secretion pathway, the localization of Hsp30, a protein that is normally localized in the cytoplasmic membrane, was probed using a Hsp30-GFP fusion reporter. In plasma-treated cells, the fusion protein was found to mislocalize to the granules in the cell cytoplasm, which appears to be the result of disrupted transport of proteins from ER to the cytoplasmic membrane [100]. These observations together strongly indicate that the treatment of cells with non-thermal plasma leads to the stress in ER and affects the protein traffic in the secretory pathway.

Besides its effects on protein folding, the effects of plasma on translation were also investigated. Two types of aggregates that form in the cytosol of eukaryotic cells in the response to a stress that affects the translation - in yeast including heat shock, high 
concentration of ethanol, or treatment with sodium azide - are processing bodies (P-bodies) and stress granules (SG). While P-bodies contain translationally repressed mRNAs and a set of mRNA decay enzymes and are involved in mRNA degradation, SGs contain mRNA together with multiple components of the translation machinery and represent a storage form of mRNA that is not translated at the moment [117-120]. Formation of both types of aggregates, P-bodies and SGs, in plasma-treated cells was shown again by visualization of these aggregates by expression of GFP tagged proteins Dcp1-GFP, Dcp2-GFP (subunits of mRNA decapping complex) and Dhh1-GFP (mRNA decapping activator) as markers of P-bodies and Ngr1-GFP (RNA binding protein) and Pab1-GFP (poly(A) binding protein), markers of SGs [100]. Appearance of P-bodies implies that cell response to plasma includes a global repression of translation. Formation of SGs has been previously described to occur in yeast only under serious stresses such as glucose deprivation [121], high concentration of ethanol [122] and severe heat shock [123] or combination of mild stresses [124]. It is not clear which of the stresses produced by plasma induce the formation of SGs, but it is very likely that it is multiple different stresses that combine [100].

Together, these experiments show that besides the manifestation of typical hallmarks of stress, a response by several stress responsive pathways occurs in plasma-treated yeast (Figure 2). Deletion experiments described above together with these data show that the stress response pathways are in fact effective and their activation results in increased cell survival. This is further corroborated by the fact that pretreatment of cells with mild heat-shock, which activates most of these stress-response pathways, also improves yeast resistance to plasma [106]. Maintenance of cell survival by these stress response pathways, including increased plasma resistance of pretreated cell, likely results from transcriptional activation of many genes encoding for chaperones, enzymes involved in ROS detoxification and others. It is, thus, interesting that proteomic analysis of cells treated by plasma did not show an increased expression of stress-response genes [125]. As for now, there is no reasonable explanation for this contradiction. It needs to be addressed in the future to come.

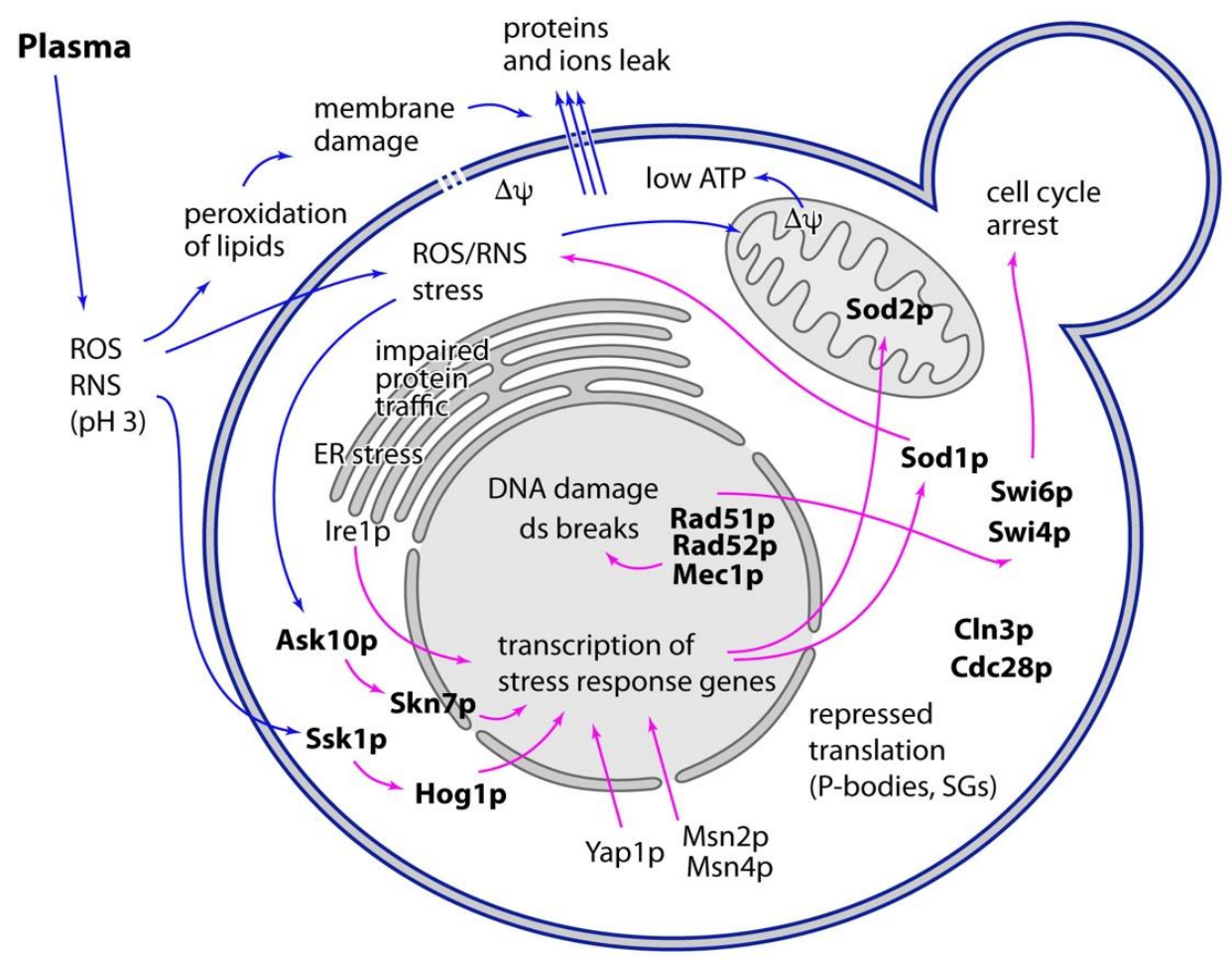

Figure 2. Summary of cold plasma effects on yeast cell. Treatment of cells with plasma induces multiple types of stress and damage (blue arrows). Cellular stress response pathways (purple arrows) act to protect cell from damage. Components of these pathways that are known to affect the cell survival (e.g., deletion of genes encoding for these components results in increased sensitivity of cells to plasma) are shown in bold. 


\title{
8. Conclusions
}

Taken together, treatment with non-thermal plasma induces several types of stress in yeast cells. These stresses seem to be triggered by the presence of reactive particles, e.g., reactive oxygen and nitrogen species, that react with many cellular components, such as proteins, DNA and lipids. Plasma-induced damage of all of these components clearly contributes to cell killing. Although many targets of plasma have been described, there are not enough data yet to understand the contribution of individual defects to cell dying. Moreover, it is clear that while some of the observed effects of plasma are independent, e.g., direct chemical damage of multiple cellular components by reactive particles originating from plasma, others may be related. The relations between these effects, especially the casual relations, can be sometimes deduced from our knowledge of cell biology, but are generally hard to understand from the descriptive image of plasma-treated cells we have so far.

Other aspect of plasma treatment that is not yet understood is the contribution of individual reactive species to the damage of specific targets. Addressing this has been attempted by using scavengers specific for different reactive particles [47], as well as using yeast strains deficient in enzymes participating in specific detoxification pathways (e.g., superoxide by superoxide dismutases, see above). Using these or similar approaches will possibly give us a complex image of how cell components get damaged by individual chemical components of plasma and which response pathways are activated in response to what damage.

Several of the stress response pathways that have been shown to be activated in case of plasma treatment are known to respond to multiple types of stress. For example, the MAPK pathway involving Hog1p can be activated by oxidative stress, as well as by acidic stress [126]. As both of these types of stress are present in plasma treatment, it may be that either one of these two or both of them together play a relevant role in inducing the response to plasma. As of now, contributions of particular stresses have generally not been established. Even though at the first sight this may look as a nonproductive nitpicking, it may indeed have consequences in specific situations, for example when cells are treated with plasma in the buffered environment or in the presence of reactive particles scavenger.

We believe that yeast $S$. cerevisiae represents an excellent simple eukaryotic model, in which all of the outlined aspects of plasma effects on cells can be addressed and that our understanding of the processes in this organism will also be directly relevant to the effects of plasma on more complicated mammalian cells.

Author Contributions: Manuscript concept, P.P.; writing, P.P.; review and editing, P.P. and Z.M.; figures preparation, P.P. All authors have read and agreed to the published version of the manuscript.

Funding: This work was supported by the Scientific Grant Agency of Ministry of Education of Slovak Republic VEGA 1/0459/20 and Slovak Research and Development Agency APVV-17-0382.

Institutional Review Board Statement: Not applicable.

Informed Consent Statement: Not applicable.

Data Availability Statement: Not applicable.

Acknowledgments: The authors would like to thank Katarína Polčicová for the help with the manuscript.

Conflicts of Interest: The authors declare no conflict of interest.

\author{
Abbreviations \\ $\Delta \psi \quad$ transmembrane potential \\ ARTP atmospheric and room temperature plasmas \\ DAPI $\quad 4^{\prime}$,6-diamidino-2-phenylindole \\ DTT dithiotreitol
}




$\begin{array}{ll}\text { ER } & \text { endoplasmic reticulum } \\ \text { GFP } & \text { green fluorescent protein } \\ \text { MAPK } & \text { mitogen-activated protein kinase } \\ \text { MDA } & \text { malonedialdehyde } \\ \text { PBS } & \text { phosphate buffered saline } \\ \text { PTP } & \text { permeability transition pore } \\ \text { RNS } & \text { reactive nitrogen species } \\ \text { ROS } & \text { reactive oxygen species } \\ \text { SG } & \text { stress granule } \\ \text { STRE } & \text { stress response element } \\ \text { TMRM } & \text { tetramethylrhodamine methyl ester } \\ \text { YPD } & \text { yeast extract, peptone, dextrose (cultivation medium) }\end{array}$

\section{References}

1. Laroussi, M.; Kong, M.; Morfill, G.; Stolz, W. Plasma Medicine: Applications of Low-Temperature Gas Plasmas in Medicine and Biology; Cambridge University Press: Cambridge, UK, 2012.

2. Machala, Z.; Hensel, K.; Akishev, Y. Plasma for bio-decontamination, medicine and food security. In NATO Science for Peace and Security Series A: Chemistry and Biology; Springer Science \& Business Media: Berlin/Heidelberg, Germany, 2012.

3. Fridman, A.A.; Friedman, G.G. Plasma Medicine; John Wiley \& Sons: Chichester, UK, 2013.

4. Von Woedtke, T.; Reuter, S.; Masur, K.; Weltmann, K.-D. Plasmas for medicine. Phys. Rep. 2013, 530, 291-320. [CrossRef]

5. Scholtz, V.; Pazlarová, J.; Soušková, H.; Khun, J.; Julák, J. Nonthermal plasma-A tool for decontamination and disinfection. Biotechnol. Adv. 2015, 33, 1108-1119. [CrossRef] [PubMed]

6. Misra, N.; Segat, A.; Cullen, P. Atmospheric-Pressure Non-Thermal Plasma Decontamination of Foods. Adv. Food Biotechnol. 2015, 565-574.

7. Puač, N.; Gherardi, M.; Shiratani, M. Plasma agriculture: A rapidly emerging field. Plasma Process. Polym. 2018, 15, 1700174. [CrossRef]

8. Bernhardt, T.; Semmler, M.L.; Schäfer, M.; Bekeschus, S.; Emmert, S.; Boeckmann, L. Plasma medicine: Applications of cold atmospheric pressure plasma in dermatology. Oxid. Med. Cell. Longev. 2019, 2019, 3873928. [CrossRef]

9. Bekeschus, S.; Schmidt, A.; Weltmann, K.-D.; von Woedtke, T. The plasma jet kINPen-A powerful tool for wound healing. Clin. Plasma Med. 2016, 4, 19-28. [CrossRef]

10. Tanaka, H.; Ishikawa, K.; Mizuno, M.; Toyokuni, S.; Kajiyama, H.; Kikkawa, F.; Metelmann, H.-R.; Hori, M. State of the art in medical applications using non-thermal atmospheric pressure plasma. Rev. Mod. Plasma Phys. 2017, 1, 3. [CrossRef]

11. Metelmann, H.-R.; Von Woedtke, T.; Weltmann, K.-D. Comprehensive Clinical Plasma Medicine: Cold Physical Plasma for Medical Application; Springer: Berlin/Heidelberg, Germany, 2018.

12. Botstein, D.; Chervitz, S.A.; Cherry, J.M. Yeast as a model organism. Science 1997, 277, 1259-1260. [CrossRef] [PubMed]

13. Madeo, F.; Engelhardt, S.; Herker, E.; Lehmann, N.; Maldener, C.; Proksch, A.; Wissing, S.; Frohlich, K.U. Apoptosis in yeast: A new model system with applications in cell biology and medicine. Curr. Genet. 2002, 41, 208-216. [CrossRef] [PubMed]

14. Sarto-Jackson, I.; Tomaska, L. How to bake a brain: Yeast as a model neuron. Curr. Genet. 2016, 62, 347-370. [CrossRef] [PubMed]

15. Zhao, R.Y. Yeast for virus research. Microb. Cell 2017, 4, 311-330. [CrossRef]

16. Mager, W.H.; Winderickx, J. Yeast as a model for medical and medicinal research. Trends Pharmacol. Sci. 2005, 26, 265-273. [CrossRef]

17. Kim, S.; Park, J.; Kim, T.; Lee, J.-S. The functional study of human proteins using humanized yeast. J. Microbiol. 2020, 58, 343-349. [CrossRef]

18. Lee, K.; Paek, K.H.; Ju, W.T.; Lee, Y. Sterilization of bacteria, yeast, and bacterial endospores by atmospheric-pressure cold plasma using helium and oxygen. J. Microbiol. 2006, 44, 269-275. [PubMed]

19. Machala, Z.; Jedlovský, I.; Chládeková, L.; Pongrác, B.; Giertl, D.; Janda, M.; Šikurová, L.; Polčic, P. DC discharges in atmospheric air for bio-decontamination-spectroscopic methods for mechanism identification. Eur. Phys. J. D 2009, 54, 195-204. [CrossRef]

20. Barekzi, N.; Laroussi, M. Dose-dependent killing of leukemia cells by low-temperature plasma. J. Phys. D Appl. Phys. 2012, 45, 422002. [CrossRef]

21. Bauer, G. Intercellular singlet oxygen-mediated bystander signaling triggered by long-lived species of cold atmospheric plasma and plasma-activated medium. Redox Biol. 2019, 26, 101301. [CrossRef] [PubMed]

22. Sousa, J.S.; Bauville, G.; Lacour, B.; Puech, V.; Touzeau, M.; Ravanat, J.-L. DNA oxidation by singlet delta oxygen produced by atmospheric pressure microdischarges. Appl. Phys. Lett. 2010, 97, 141502. [CrossRef]

23. Machala, Z.; Tarabova, B.; Hensel, K.; Spetlikova, E.; Sikurová, L.; Lukes, P. Formation of ROS and RNS in Water Electro-S prayed through Transient Spark Discharge in Air and their Bactericidal Effects. Plasma Process. Polym. 2013, 10, 649-659. [CrossRef]

24. Lukes, P.; Dolezalova, E.; Sisrova, I.; Clupek, M. Aqueous-phase chemistry and bactericidal effects from an air discharge plasma in contact with water: Evidence for the formation of peroxynitrite through a pseudo-second-order post-discharge reaction of H2O2 and HNO2. Plasma Sources Sci. Technol. 2014, 23, 015019. [CrossRef] 
25. Polčic, P.; Pakosová, L.; Chovančíková, P.; Machala, Z. Reactive cold plasma particles generate oxidative stress in yeast but do not trigger apoptosis. Can. J. Microbiol. 2018, 64, 367-375. [CrossRef] [PubMed]

26. Ryu, Y.H.; Kim, Y.H.; Lee, J.Y.; Shim, G.B.; Uhm, H.S.; Park, G.; Choi, E.H. Effects of background fluid on the efficiency of inactivating yeast with non-thermal atmospheric pressure plasma. PLoS ONE 2013, 8, e66231. [CrossRef]

27. Carmelo, V.; Bogaerts, P.; Sá-Correia, I. Activity of plasma membrane H+-ATPase and expression of PMA1 and PMA2 genes in Saccharomyces cerevisiae cells grown at optimal and low pH. Arch. Microbiol. 1996, 166, 315-320. [CrossRef] [PubMed]

28. Kim, S.J.; Chung, T.; Bae, S.; Leem, S. Induction of apoptosis in human breast cancer cells by a pulsed atmospheric pressure plasma jet. Appl. Phys. Lett. 2010, 97, 023702. [CrossRef]

29. Ahn, H.J.; Kim, K.I.; Kim, G.; Moon, E.; Yang, S.S.; Lee, J.S. Atmospheric-pressure plasma jet induces apoptosis involving mitochondria via generation of free radicals. PLoS ONE 2011, 6, e28154. [CrossRef]

30. Tan, X.; Zhao, S.; Lei, Q.; Lu, X.; He, G.; Ostrikov, K. Single-cell-precision microplasma-induced cancer cell apoptosis. PLoS ONE 2014, 9, e101299. [CrossRef] [PubMed]

31. Liang, Q.; Li, W.; Zhou, B. Caspase-independent apoptosis in yeast. Biochim. Biophys. Acta 2008, 1783, 1311-1319. [CrossRef] [PubMed]

32. Mazzoni, C.; Falcone, C. Caspase-dependent apoptosis in yeast. Biochim. Biophys. Acta 2008, 1783, 1320-1327. [CrossRef]

33. Carmona-Gutierrez, D.; Eisenberg, T.; Buttner, S.; Meisinger, C.; Kroemer, G.; Madeo, F. Apoptosis in yeast: Triggers, pathways, subroutines. Cell Death Differ. 2010, 17, 763-773. [CrossRef] [PubMed]

34. Strich, R. Programmed Cell Death Initiation and Execution in Budding Yeast. Genetics 2015, 200, 1003-1014. [CrossRef] [PubMed]

35. Carmona-Gutierrez, D.; Bauer, M.A.; Zimmermann, A.; Aguilera, A.; Austriaco, N.; Ayscough, K.; Balzan, R.; Bar-Nun, S.; Barrientos, A.; Belenky, P.; et al. Guidelines and recommendations on yeast cell death nomenclature. Microb. Cell 2018, 5, 4-31. [CrossRef] [PubMed]

36. Ma, R.; Feng, H.; Liang, Y.; Zhang, Q.; Tian, Y.; Su, B.; Zhang, J.; Fang, J. An atmospheric-pressure cold plasma leads to apoptosis in Saccharomyces cerevisiae by accumulating intracellular reactive oxygen species and calcium. J. Phys. D Appl. Phys. 2013, 46, 285401. [CrossRef]

37. Čtvrtečková, L.; Pichová, A.; Scholtz, V.; Khun, J.; Julák, J. Non-thermal plasma-induced apoptosis in yeast Saccharomyces cerevisiae. Contrib. Plasma Phys. 2019, 59, e201800064. [CrossRef]

38. Madeo, F.; Herker, E.; Maldener, C.; Wissing, S.; Lachelt, S.; Herlan, M.; Fehr, M.; Lauber, K.; Sigrist, S.J.; Wesselborg, S.; et al. A caspase-related protease regulates apoptosis in yeast. Mol. Cell 2002, 9, 911-917. [CrossRef]

39. Wissing, S.; Ludovico, P.; Herker, E.; Buttner, S.; Engelhardt, S.M.; Decker, T.; Link, A.; Proksch, A.; Rodrigues, F.; Corte-Real, M.; et al. An AIF orthologue regulates apoptosis in yeast. J. Cell Biol. 2004, 166, 969-974. [CrossRef] [PubMed]

40. Buttner, S.; Eisenberg, T.; Carmona-Gutierrez, D.; Ruli, D.; Knauer, H.; Ruckenstuhl, C.; Sigrist, C.; Wissing, S.; Kollroser, M.; Frohlich, K.U.; et al. Endonuclease G regulates budding yeast life and death. Mol. Cell 2007, 25, 233-246. [CrossRef] [PubMed]

41. Ayala, A.; Munoz, M.F.; Arguelles, S. Lipid peroxidation: Production, metabolism, and signaling mechanisms of malondialdehyde and 4-hydroxy-2-nonenal. Oxid. Med. Cell. Longev. 2014, 2014, 360438. [CrossRef] [PubMed]

42. Reilly, C.A.; Aust, S.D. Measurement of lipid peroxidation. Curr. Protoc. Toxicol. 2001. [CrossRef]

43. Joshi, S.G.; Cooper, M.; Yost, A.; Paff, M.; Ercan, U.K.; Fridman, G.; Friedman, G.; Fridman, A.; Brooks, A.D. Nonthermal dielectric-barrier discharge plasma-induced inactivation involves oxidative DNA damage and membrane lipid peroxidation in Escherichia coli. Antimicrob. Agents Chemother. 2011, 55, 1053-1062. [CrossRef] [PubMed]

44. Doležalová, E.; Lukeš, P. Membrane damage and active but nonculturable state in liquid cultures of Escherichia coli treated with an atmospheric pressure plasma jet. Bioelectrochemistry 2015, 103, 7-14. [CrossRef]

45. Martin, C.E.; Oh, C.S.; Jiang, Y. Regulation of long chain unsaturated fatty acid synthesis in yeast. Biochim. Biophys. Acta 2007, 1771, 271-285. [CrossRef] [PubMed]

46. Stukey, J.E.; McDonough, V.M.; Martin, C.E. Isolation and characterization of OLE1, a gene affecting fatty acid desaturation from Saccharomyces cerevisiae. J. Biol. Chem. 1989, 264, 16537-16544. [CrossRef]

47. Xu, H.; Zhu, Y.; Du, M.; Wang, Y.; Ju, S.; Ma, R.; Jiao, Z. Subcellular mechanism of microbial inactivation during water disinfection by cold atmospheric-pressure plasma. Water Res. 2021, 188, 116513. [CrossRef] [PubMed]

48. Bernardi, P.; Rasola, A.; Forte, M.; Lippe, G. The Mitochondrial Permeability Transition Pore: Channel Formation by F-ATP Synthase, Integration in Signal Transduction, and Role in Pathophysiology. Physiol. Rev. 2015, 95, 1111-1155. [CrossRef]

49. Yamada, A.; Yamamoto, T.; Yoshimura, Y.; Gouda, S.; Kawashima, S.; Yamazaki, N.; Yamashita, K.; Kataoka, M.; Nagata, T.; Terada, H.; et al. Ca2+-induced permeability transition can be observed even in yeast mitochondria under optimized experimental conditions. Biochim. Biophys. Acta 2009, 1787, 1486-1491. [CrossRef] [PubMed]

50. Carraro, M.; Bernardi, P. Calcium and reactive oxygen species in regulation of the mitochondrial permeability transition and of programmed cell death in yeast. Cell Calcium 2016, 60, 102-107. [CrossRef] [PubMed]

51. Arjunan, K.P.; Sharma, V.K.; Ptasinska, S. Effects of atmospheric pressure plasmas on isolated and cellular DNA-A review. Int. J. Mol. Sci. 2015, 16, 2971-3016. [CrossRef]

52. Wende, K.; Straßenburg, S.; Haertel, B.; Harms, M.; Holtz, S.; Barton, A.; Masur, K.; von Woedtke, T.; Lindequist, U. Atmospheric pressure plasma jet treatment evokes transient oxidative stress in HaCaT keratinocytes and influences cell physiology. Cell Biol. Int. 2014, 38, 412-425. [CrossRef] [PubMed] 
53. Brun, P.; Brun, P.; Vono, M.; Venier, P.; Tarricone, E.; Deligianni, V.; Martines, E.; Zuin, M.; Spagnolo, S.; Cavazzana, R.; et al. Disinfection of ocular cells and tissues by atmospheric-pressure cold plasma. PLoS ONE 2012, 7, e33245. [CrossRef] [PubMed]

54. Zhang, X.; Zhang, X.F.; Li, H.P.; Wang, L.Y.; Zhang, C.; Xing, X.H.; Bao, C.Y. Atmospheric and room temperature plasma (ARTP) as a new powerful mutagenesis tool. Appl. Microbiol. Biotechnol. 2014, 98, 5387-5396. [CrossRef] [PubMed]

55. Ottenheim, C.; Nawrath, M.; Wu, J.C. Microbial mutagenesis by atmospheric and room-temperature plasma (ARTP): The latest development. Bioresour. Bioprocess. 2018, 5, 12. [CrossRef]

56. Tian, T.; Wu, D.; Ng, C.T.; Yang, H.; Sun, J.; Liu, J.; Lu, J. A multiple-step strategy for screening Saccharomyces cerevisiae strains with improved acid tolerance and aroma profiles. Appl. Microbiol. Biotechnol. 2020, 104, 3097-3107. [CrossRef]

57. Symington, L.S. Role of RAD52 epistasis group genes in homologous recombination and double-strand break repair. Microbiol. Mol. Biol. Rev. 2002, 66, 630-670. [CrossRef] [PubMed]

58. Lee, Y.; Kim, K.; Kang, K.T.; Lee, J.S.; Yang, S.S.; Chung, W.H. Atmospheric-pressure plasma jet induces DNA double-strand breaks that require a Rad51-mediated homologous recombination for repair in Saccharomyces cerevisiae. Arch. Biochem. Biophys. 2014, 560, 1-9. [CrossRef] [PubMed]

59. Gasior, S.L.; Olivares, H.; Ear, U.; Hari, D.M.; Weichselbaum, R.; Bishop, D.K. Assembly of RecA-like recombinases: Distinct roles for mediator proteins in mitosis and meiosis. Proc. Natl. Acad. Sci. USA 2001, 98, 8411-8418. [CrossRef] [PubMed]

60. Sugiyama, T.; Kowalczykowski, S.C. Rad52 protein associates with replication protein A (RPA)-single-stranded DNA to accelerate Rad51-mediated displacement of RPA and presynaptic complex formation. J. Biol. Chem. 2002, 277, 31663-31672. [CrossRef] [PubMed]

61. Weinert, T.A.; Kiser, G.L.; Hartwell, L.H. Mitotic checkpoint genes in budding yeast and the dependence of mitosis on DNA replication and repair. Genes Dev. 1994, 8, 652-665. [CrossRef]

62. Longhese, M.P.; Foiani, M.; Muzi-Falconi, M.; Lucchini, G.; Plevani, P. DNA damage checkpoint in budding yeast. EMBO J. 1998, 17, 5525-5528. [CrossRef]

63. Guo, L.; Zhao, Y.; Liu, D.; Liu, Z.; Chen, C.; Xu, R.; Tian, M.; Wang, X.; Chen, H.; Kong, M.G. Cold atmospheric-pressure plasma induces DNA-protein crosslinks through protein oxidation. Free Radic. Res. 2018, 52, 783-798. [CrossRef]

64. Fielden, J.; Ruggiano, A.; Popovic, M.; Ramadan, K. DNA protein crosslink proteolysis repair: From yeast to premature ageing and cancer in humans. DNA Repair 2018, 71, 198-204. [CrossRef] [PubMed]

65. Chvalova, K.; Brabec, V.; Kasparkova, J. Mechanism of the formation of DNA-protein cross-links by antitumor cisplatin. Nucleic Acids Res. 2007, 35, 1812-1821. [CrossRef] [PubMed]

66. Ming, X.; Groehler, A.T.; Michaelson-Richie, E.D.; Villalta, P.W.; Campbell, C.; Tretyakova, N.Y. Mass Spectrometry Based Proteomics Study of Cisplatin-Induced DNA-Protein Cross-Linking in Human Fibrosarcoma (HT1080) Cells. Chem. Res. Toxicol. 2017, 30, 980-995. [CrossRef]

67. Goffeau, A.; Barrell, B.G.; Bussey, H.; Davis, R.W.; Dujon, B.; Feldmann, H.; Galibert, F.; Hoheisel, J.D.; Jacq, C.; Johnston, M. Life with 6000 genes. Science 1996, 274, 546-567. [CrossRef]

68. Winzeler, E.A.; Shoemaker, D.D.; Astromoff, A.; Liang, H.; Anderson, K.; Andre, B.; Bangham, R.; Benito, R.; Boeke, J.D.; Bussey, H. Functional characterization of the S. cerevisiae genome by gene deletion and parallel analysis. Science 1999, 285, 901-906. [CrossRef]

69. Rothstein, R. [19] Targeting, disruption, replacement, and allele rescue: Integrative DNA transformation in yeast. Methods Enzymol. 1991, 194, 281-301. [PubMed]

70. Gardner, J.M.; Jaspersen, S.L. Manipulating the yeast genome: Deletion, mutation, and tagging by PCR. In Yeast Genetics; Springer: Berlin/Heidelberg, Germany, 2014; pp. 45-78.

71. Chang, E.C.; Crawford, B.F.; Hong, Z.; Bilinski, T.; Kosman, D.J. Genetic and biochemical characterization of Cu,Zn superoxide dismutase mutants in Saccharomyces cerevisiae. J. Biol. Chem. 1991, 266, 4417-4424. [CrossRef]

72. Costa, V.; Amorim, M.A.; Reis, E.; Quintanilha, A.; Moradas-Ferreira, P. Mitochondrial superoxide dismutase is essential for ethanol tolerance of Saccharomyces cerevisiae in the post-diauxic phase. Microbiology 1997, 143 Pt 5, 1649-1656. [CrossRef]

73. Galiazzo, F.; Labbe-Bois, R. Regulation of $\mathrm{Cu}, \mathrm{Zn}$ - and Mn-superoxide dismutase transcription in Saccharomyces cerevisiae. FEBS Lett. 1993, 315, 197-200. [CrossRef]

74. Spevak, W.; Fessl, F.; Rytka, J.; Traczyk, A.; Skoneczny, M.; Ruis, H. Isolation of the catalase T structural gene of Saccharomyces cerevisiae by functional complementation. Mol. Cell. Biol. 1983, 3, 1545-1551. [CrossRef] [PubMed]

75. Cohen, G.; Fessl, F.; Traczyk, A.; Rytka, J.; Ruis, H. Isolation of the catalase A gene of Saccharomyces cerevisiae by complementation of the cta1 mutation. Mol. Gen. Genet. 1985, 200, 74-79. [CrossRef] [PubMed]

76. Petrova, V.Y.; Drescher, D.; Kujumdzieva, A.V.; Schmitt, M.J. Dual targeting of yeast catalase A to peroxisomes and mitochondria. Biochem. J. 2004, 380, 393-400. [CrossRef]

77. Izawa, S.; Inoue, Y.; Kimura, A. Importance of catalase in the adaptive response to hydrogen peroxide: Analysis of acatalasaemic Saccharomyces cerevisiae. Biochem. J. 1996, 320 Pt 1, 61-67. [CrossRef]

78. Feng, H.; Wang, R.; Sun, P.; Wu, H.; Liu, Q.; Fang, J.; Zhu, W.; Li, F.; Zhang, J. A study of eukaryotic response mechanisms to atmospheric pressure cold plasma by using Saccharomyces cerevisiae single gene mutants. Appl. Phys. Lett. 2010, 97, 131501. [CrossRef]

79. Ikner, A.; Shiozaki, K. Yeast signaling pathways in the oxidative stress response. Mutat. Res. 2005, 569, 13-27. [CrossRef] [PubMed] 
80. Rep, M.; Proft, M.; Remize, F.; Tamas, M.; Serrano, R.; Thevelein, J.M.; Hohmann, S. The Saccharomyces cerevisiae Sko1p transcription factor mediates HOG pathway-dependent osmotic regulation of a set of genes encoding enzymes implicated in protection from oxidative damage. Mol. Microbiol. 2001, 40, 1067-1083. [CrossRef] [PubMed]

81. Proft, M.; Struhl, K. Hog1 kinase converts the Sko1-Cyc8-Tup1 repressor complex into an activator that recruits SAGA and SWI/SNF in response to osmotic stress. Mol. Cell 2002, 9, 1307-1317. [CrossRef]

82. Maeda, T.; Wurgler-Murphy, S.M.; Saito, H. A two-component system that regulates an osmosensing MAP kinase cascade in yeast. Nature 1994, 369, 242-245. [CrossRef]

83. Li, S.; Ault, A.; Malone, C.L.; Raitt, D.; Dean, S.; Johnston, L.H.; Deschenes, R.J.; Fassler, J.S. The yeast histidine protein kinase, Sln1p, mediates phosphotransfer to two response regulators, Ssk1p and Skn7p. EMBO J. 1998, 17, 6952-6962. [CrossRef] [PubMed]

84. Brown, J.L.; North, S.; Bussey, H. SKN7, a yeast multicopy suppressor of a mutation affecting cell wall beta-glucan assembly, encodes a product with domains homologous to prokaryotic two-component regulators and to heat shock transcription factors. $J$. Bacteriol. 1993, 175, 6908-6915. [CrossRef] [PubMed]

85. Krems, B.; Charizanis, C.; Entian, K.D. The response regulator-like protein Pos9/Skn7 of Saccharomyces cerevisiae is involved in oxidative stress resistance. Curr. Genet. 1996, 29, 327-334. [CrossRef] [PubMed]

86. Lee, J.; Godon, C.; Lagniel, G.; Spector, D.; Garin, J.; Labarre, J.; Toledano, M.B. Yap1 and Skn7 control two specialized oxidative stress response regulons in yeast. J. Biol. Chem. 1999, 274, 16040-16046. [CrossRef]

87. Page, N.; Sheraton, J.; Brown, J.L.; Stewart, R.C.; Bussey, H. Identification of ASK10 as a multicopy activator of Skn7p-dependent transcription of a HIS3 reporter gene. Yeast 1996, 12, 267-272. [CrossRef]

88. Cohen, T.J.; Lee, K.; Rutkowski, L.H.; Strich, R. Ask10p mediates the oxidative stress-induced destruction of the Saccharomyces cerevisiae C-type cyclin Ume3p/Srb11p. Eukaryot. Cell 2003, 2, 962-970. [CrossRef] [PubMed]

89. Mendenhall, M.D.; Hodge, A.E. Regulation of Cdc28 cyclin-dependent protein kinase activity during the cell cycle of the yeast Saccharomyces cerevisiae. Microbiol. Mol. Biol. Rev. 1998, 62, 1191-1243. [CrossRef]

90. de Bruin, R.A.; McDonald, W.H.; Kalashnikova, T.I.; Yates, J., 3rd; Wittenberg, C. Cln3 activates G1-specific transcription via phosphorylation of the SBF bound repressor Whi5. Cell 2004, 117, 887-898. [CrossRef] [PubMed]

91. Costanzo, M.; Nishikawa, J.L.; Tang, X.; Millman, J.S.; Schub, O.; Breitkreuz, K.; Dewar, D.; Rupes, I.; Andrews, B.; Tyers, M. CDK activity antagonizes Whi5, an inhibitor of G1/S transcription in yeast. Cell 2004, 117, 899-913. [CrossRef] [PubMed]

92. Wittenberg, C.; Reed, S.I. Cell cycle-dependent transcription in yeast: Promoters, transcription factors, and transcriptomes. Oncogene 2005, 24, 2746-2755. [CrossRef]

93. Sidorova, J.M.; Breeden, L.L. Rad53-dependent phosphorylation of Swi6 and down-regulation of CLN1 and CLN2 transcription occur in response to DNA damage in Saccharomyces cerevisiae. Genes Dev. 1997, 11, 3032-3045. [CrossRef] [PubMed]

94. Sidorova, J.M.; Breeden, L.L. Rad53 checkpoint kinase phosphorylation site preference identified in the Swi6 protein of Saccharomyces cerevisiae. Mol. Cell. Biol. 2003, 23, 3405-3416. [CrossRef] [PubMed]

95. Chiu, J.; Tactacan, C.M.; Tan, S.X.; Lin, R.C.; Wouters, M.A.; Dawes, I.W. Cell cycle sensing of oxidative stress in Saccharomyces cerevisiae by oxidation of a specific cysteine residue in the transcription factor Swi6p. J. Biol. Chem. 2011, 286, 5204-5214. [CrossRef] [PubMed]

96. Enserink, J.M.; Hombauer, H.; Huang, M.E.; Kolodner, R.D. Cdc28/Cdk1 positively and negatively affects genome stability in S. cerevisiae. J. Cell Biol. 2009, 185, 423-437. [CrossRef] [PubMed]

97. Temple, M.D.; Perrone, G.G.; Dawes, I.W. Complex cellular responses to reactive oxygen species. Trends Cell Biol. 2005, 15, 319-326. [CrossRef] [PubMed]

98. Kuge, S.; Arita, M.; Murayama, A.; Maeta, K.; Izawa, S.; Inoue, Y.; Nomoto, A. Regulation of the yeast Yap1p nuclear export signal is mediated by redox signal-induced reversible disulfide bond formation. Mol. Cell. Biol. 2001, 21, 6139-6150. [CrossRef]

99. Okazaki, S.; Tachibana, T.; Naganuma, A.; Mano, N.; Kuge, S. Multistep disulfide bond formation in Yap1 is required for sensing and transduction of $\mathrm{H} 2 \mathrm{O} 2$ stress signal. Mol. Cell 2007, 27, 675-688. [CrossRef]

100. Itooka, K.; Takahashi, K.; Izawa, S. Fluorescence microscopic analysis of antifungal effects of cold atmospheric pressure plasma in Saccharomyces cerevisiae. Appl. Microbiol. Biotechnol. 2016, 100, 9295-9304. [CrossRef]

101. Martinez-Pastor, M.T.; Marchler, G.; Schuller, C.; Marchler-Bauer, A.; Ruis, H.; Estruch, F. The Saccharomyces cerevisiae zinc finger proteins Msn2p and Msn4p are required for transcriptional induction through the stress response element (STRE). EMBO J. 1996, 15, 2227-2235. [CrossRef] [PubMed]

102. Görner, W.; Durchschlag, E.; Martinez-Pastor, M.T.; Estruch, F.; Ammerer, G.; Hamilton, B.; Ruis, H.; Schüller, C. Nuclear localization of the $\mathrm{C} 2 \mathrm{H} 2$ zinc finger protein Msn2p is regulated by stress and protein kinase A activity. Genes Dev. 1998, 12, 586-597. [CrossRef] [PubMed]

103. Schmitt, A.P.; McEntee, K. Msn2p, a zinc finger DNA-binding protein, is the transcriptional activator of the multistress response in Saccharomyces cerevisiae. Proc. Natl. Acad. Sci. USA 1996, 93, 5777-5782. [CrossRef] [PubMed]

104. Kelley, R.; Ideker, T. Genome-wide fitness and expression profiling implicate Mga2 in adaptation to hydrogen peroxide. PLoS Genet. 2009, 5, e1000488. [CrossRef] [PubMed]

105. MacIsaac, K.D.; Wang, T.; Gordon, D.B.; Gifford, D.K.; Stormo, G.D.; Fraenkel, E. An improved map of conserved regulatory sites for Saccharomyces cerevisiae. BMC Bioinf. 2006, 7, 1-14. [CrossRef] [PubMed] 
106. Itooka, K.; Takahashi, K.; Kimata, Y.; Izawa, S. Cold atmospheric pressure plasma causes protein denaturation and endoplasmic reticulum stress in Saccharomyces cerevisiae. Appl. Microbiol. Biotechnol. 2018, 102, 2279-2288. [CrossRef]

107. Bosl, B.; Grimminger, V.; Walter, S. The molecular chaperone Hsp104-a molecular machine for protein disaggregation. J. Struct. Biol. 2006, 156, 139-148. [CrossRef] [PubMed]

108. Wong, C.M.; Zhou, Y.; Ng, R.W.; Kung Hf, H.F.; Jin, D.Y. Cooperation of yeast peroxiredoxins Tsa1p and Tsa2p in the cellular defense against oxidative and nitrosative stress. J. Biol. Chem. 2002, 277, 5385-5394. [CrossRef]

109. Rand, J.D.; Grant, C.M. The thioredoxin system protects ribosomes against stress-induced aggregation. Mol. Biol. Cell 2006, 17, 387-401. [CrossRef] [PubMed]

110. Craig, E.A.; Jacobsen, K. Mutations of the heat inducible 70 kilodalton genes of yeast confer temperature sensitive growth. Cell 1984, 38, 841-849. [CrossRef]

111. Werner-Washburne, M.; Stone, D.E.; Craig, E.A. Complex interactions among members of an essential subfamily of hsp70 genes in Saccharomyces cerevisiae. Mol. Cell. Biol. 1987, 7, 2568-2577. [CrossRef]

112. Hernández-Elvira, M.; Torres-Quiroz, F.; Escamilla-Ayala, A.; Domínguez-Martin, E.; Escalante, R.; Kawasaki, L.; Ongay-Larios, L.; Coria, R. The unfolded protein response pathway in the yeast Kluyveromyces lactis. a comparative view among yeast species. Cells 2018, 7, 106. [CrossRef] [PubMed]

113. $\mathrm{Wu}, \mathrm{H} . ; \mathrm{Ng}$, B.S.; Thibault, G. Endoplasmic reticulum stress response in yeast and humans. Biosci. Rep. 2014, 34, e00118. [CrossRef] [PubMed]

114. Cox, J.S.; Shamu, C.E.; Walter, P. Transcriptional induction of genes encoding endoplasmic reticulum resident proteins requires a transmembrane protein kinase. Cell 1993, 73, 1197-1206. [CrossRef]

115. Cox, J.S.; Walter, P. A novel mechanism for regulating activity of a transcription factor that controls the unfolded protein response. Cell 1996, 87, 391-404. [CrossRef]

116. Okamura, K.; Kimata, Y.; Higashio, H.; Tsuru, A.; Kohno, K. Dissociation of Kar2p/BiP from an ER sensory molecule, Ire1p, triggers the unfolded protein response in yeast. Biochem. Biophys. Res. Commun. 2000, 279, 445-450. [CrossRef]

117. Parker, R.; Sheth, U. P bodies and the control of mRNA translation and degradation. Mol. Cell 2007, 25, 635-646. [CrossRef] [PubMed]

118. Franks, T.M.; Lykke-Andersen, J. The control of mRNA decapping and P-body formation. Mol. Cell 2008, 32, 605-615. [CrossRef] [PubMed]

119. Buchan, J.R.; Parker, R. Eukaryotic stress granules: The ins and outs of translation. Mol. Cell 2009, 36, 932-941. [CrossRef] [PubMed]

120. Balagopal, V.; Parker, R. Polysomes, P bodies and stress granules: States and fates of eukaryotic mRNAs. Curr. Opin. Cell Biol. 2009, 21, 403-408. [CrossRef]

121. Buchan, J.R.; Muhlrad, D.; Parker, R. P bodies promote stress granule assembly in Saccharomyces cerevisiae. J. Cell Biol. 2008, 183, 441-455. [CrossRef] [PubMed]

122. Kato, K.; Yamamoto, Y.; Izawa, S. Severe ethanol stress induces assembly of stress granules in Saccharomyces cerevisiae. Yeast 2011, 28, 339-347. [CrossRef] [PubMed]

123. Groušl, T.; Ivanov, P.; Frydlová, I.; Vašicová, P.; Janda, F.; Vojtová, J.; Malínská, K.; Malcová, I.; Nováková, L.; Janošková, D.; et al. Robust heat shock induces eIF2alpha-phosphorylation-independent assembly of stress granules containing eIF3 and $40 \mathrm{~S}$ ribosomal subunits in budding yeast, Saccharomyces cerevisiae. J. Cell Sci. 2009, 122, 2078-2088. [CrossRef]

124. Yamamoto, Y.; Izawa, S. Adaptive response in stress granule formation and bulk translational repression upon a combined stress of mild heat shock and mild ethanol stress in yeast. Genes Cells 2013, 18, 974-984. [CrossRef]

125. Stulić, V.; Vukušić, T.; Butorac, A.; Popović, D.; Herceg, Z. Proteomic analysis of Saccharomyces cerevisiae response to plasma treatment. Int. J. Food Microbiol. 2019, 292, 171-183. [CrossRef]

126. Guaragnella, N.; Stirpe, M.; Marzulli, D.; Mazzoni, C.; Giannattasio, S. Acid Stress Triggers Resistance to Acetic Acid-Induced Regulated Cell Death through Hog1 Activation Which Requires RTG2 in Yeast. Oxid. Med. Cell. Longev. 2019, $2019,4651062$. [CrossRef] [PubMed] 